\title{
RESTORATIVE JUSTICE CONCEPT ON JARIMAH QISHAS IN ISLAMIC CRIMINAL LAW
}

\author{
Zainuddin \\ Faculty of Law Universitas Muslim Indonesia Makassar, Indonesia \\ E-mail: zhainus@yahoo.com
}

\begin{abstract}
Essentially, Islamic law is modern law since it has recognized restorative justice for jarimah qishas (murder or torture). The concepts of restorative justice in Islamic criminal law realize fairness and balance to the offender and the victim themselves. Restorative justice in Islamic criminal law as explicitly provided in Q.S. al-Hujurat (49): 10 and Q.S. Asy-Syuura (42): 40. The Quran regulates peace and forgiveness in solving crime. The existence of peace and forgiveness aims to realize the unity and sustainability of life as a purpose of the laws. Peace and forgiveness are premium remedium while penalty is ultimun remediun in Islamic criminal law. Otherwise, in modern criminal law, penalty is premium remedium.
\end{abstract}

Keywords: forgiveness, peace, qishas, restorative justice

\begin{abstract}
Abstrak
Pada hakikatnya hukum Islam adalah hukum modern karena sudah mengenal bentuk penyelesaian restorative justice pada jarimah qishas. Konsep restorative justice dalam hukum pidana Islam dilakukan melalui perdamaian dan pemaafan dengan mewujudkan terciptanya keadilan dan keseimbangan bagi pelaku tindak pidana serta korbannya sendiri. Restorative justice dalam Hukum pidana Islam diatur secara tegas dalam Q.S. al-Hujurat (49) Ayat 10 dan Q.S. Asy-Syuura (42) Ayat 40 yang memerintahkan perdamaian dan pemaafan dalam penyelesaian tindak pidana. Adanya perdamaian dan pemaafan tersebut dalam rangka mewujudkan keutuhan dan keberlanjutan kehidupan bersama sebagai tujuan dari hukum. Perdamaian dan pemaafan merupakan premium remediun dan sanksi pidana merupakan ultimun remediun dalam hukum pidana Islam. Sebaliknya, pada hukum pidana modern, sanksi pidana merupakan premium remedium.
\end{abstract}

Kata kunci: pemaafan, perdamaian, qishas, restorative justice

\section{Introduction}

Islam is a revelation religion (divine religion) by Allah SWT to people through the last prophet Muhammad SAW. The thoughts of Islam are based on the revelation given to Muhammad SAW, and then he delivered them to his people until present. ${ }^{1}$

Quran as the first and primary legal source contains many thoughts for the benefits of human. The islamic scholars divide Quran contents into three major group namely aqidah, khuluqiyyah, and 'amaliyah. First, Aqidah relates to belief principles. Second, khuluqiyyah

Zainuddin, 2013, Hukum Zakat: Perspektif Normatif, Kesejahteraan dan Keradilan Sosial, Makassar: Alauddin University Press, p. 1-2. relates to ethics and morals, while amaliyah relates to legal aspects coming from aqwal (expressions) and af'al (human acts). Secondly, amaliyah, is divided into two parts in islamic law. The first is ibadah which discusses pattern of relation between human and God. The second is muamalah which explains the pattern of relationship amonh people. ${ }^{2}$

The basic purpose of islamic law is to protect the most important values which are religion, soul, mind, decendant and treasure. ${ }^{3}$ Tho-

\footnotetext{
Ahmad Rajafi, "Qishash dan Maqashid Al-Syariah (Analisis Pemikiran asy-Syathibi dalam Kitab Al-Muwafaqat)", Jurnal Al-Syir'ah, Vol. 8 No. 2, December 2010, p. 466.

3 Alaeldin Maghaireh, "Shariah Law and Cyber-Sectarian Conflict: How Can Islamic Criminal Law Respond To Cy-
} 
se purposes are categorized as maqashid addharuriyat or emergency purposes.

Islamic criminal law (fiqh jinayah) as a part of islamic law is Allah's sharia in regulating legal conditions about criminal act led by mukallaf (responsible people), as the result of understanding detail legal postulates of Quran and hadith. The islamic criminal law essencially contains the benefits for human life in the world and hereafter.

By looking at the conventional criminal justice system, it can be seen as if the trial is the best place to solve the legal conflict and seek justice. Every indication of criminal act, without considering the act escalation, will be led to the law enforcement which then only becomes the jurisdiction for the law enforcer. The social participation apparently becomes less significant. All will end up on the trial judgment such as penalty without considering its essence, ${ }^{4}$ thus, one of the parties will be not satisfied. Instead, it should create not only elegal justice but also the moral justice and social justice.

Islamic penalty system provides many alternative solutions of criminal act by keeping the balance of the interests of the victim, society, nation, or offender. According to Amin Suma, one of the concept of criminal responsibility in fiqh jinayah which is adaptive to the Penal Code is forgiveness institution. If somebody murders a person but the family of the victim forgive the offender, he/she is free from any punishment. ${ }^{5}$

The solving criminal case through peace and forgiveness in islamic criminal law is the implementation of restorative justice which has essensially been implemented since long ago. This concept is definitely in line with the cultural values of Indonesian people which are part

ber Crime?" International Journal of Cyber Criminology, Vol 2 Issue 2, July - December 2008, p. 337

4 Septa Candra, "Politik Hukum Pengadopsian Restorative Justice Dalam Pembaharuan Hukum Pidana”, Fiat Justisia Jurnal Ilmu Hukum, Vol. 8, No. 2, April-Juni 2014, p. 265.

5 Hambali Yusuf dan Saifullah Basri, “Model Penyelesaian Alternatif Perkara Pidana Pembunuhan Biasa menurut Hukum Islam dan Relevansinya dengan Pembaharuan Hukum Pidana Indonesia", Jurnal Hukum IUS QUIA IUSTUM, Vol. 24, No. 1, January 2017, p. 76. of local wisdom. Restorative Justice is the effort of premium remedium (primary cure). Meanwhile, what happens recently is that the penalty imposition is the first and primary sanction which is win-lose solution. Whereas, penalty is ultimum remedium or the last solution when the peace and forgiveness cannot be reached. The problems discussed in this article are: first, how the concept of restorative justice in islamic criminal law is; second, how does solving problem of jarimah qishas through restorat-ive justice approach work.

\section{Discussion}

\section{Restorative justice in Islamic Criminal Law}

Restorative justice in various perspectives is considered as a philosophical view, process, ideas, theory and an intervention. ${ }^{6}$ There are various definitions of restorative justice, one of which is expressed by Burt Galaway and Joe Hudson as follows:

A definition of restorative justice includes the following fundamental elements: "first, crime is viewed primarily as a conflict between individuals that results in injuries to victims, communities, and the offenders themselves; second, the aim of the criminal justice process should be to create peace in communities by reconciling the parties and repairing the injuries caused by the dispute; third, the criminal justice process should facilitate active participation by the victims, offenders, and their communities in order to find solutions to the conflict ${ }^{7}$

Considering there are many models developed in its application, therefore, several terminologies are used to describe the flow of restorative justice, for instance communitarian justice, positive justice, relational justice, reparative justice, and community justice. ${ }^{8}$ All refers to restorative. Zehr describes crime from restorative point of view as a violation between human re-

6 Kuat Puji Prayitno, Restorative Justice untuk Peradilan di Indonesia (Perspektif Yuridis Filosofis dalam Penegakan Hukum In Concreto)", Jurnal Dinamika Hukum, Vol. 12 Issue. 3, September 2012, p. 409.

7 Eva Achjani Zulfa, "Restorative Justice in Indonesia: Traditional Value", Indonesia Law Review, Vol. 2 No. 1, May-August 2011, page. 35.

8 Ibid., p. 33-43. 
lationships. This creates an obligation to improve the condition. Justice involves victims, offenders, and communities in finding solutions that promote improvement, reconciliation and certainty. ${ }^{9}$

Restorative justice approach is an approach focusing on the conditions of creating justice and balance for the criminals and their own victims. The criminal procedure and criminal justice mechanism focuses on criminal prosecution that is transformed into a process of dialogue and mediation to create an agreement on a fairer and more equitable criminal justice settlement for victims and offenders. ${ }^{10}$ Therefore, restorative justice is an instrument of justice that includes victims, offenders, and communities. The access to justice is not only needed by victims but also offenders.

Islamic criminal law (jinayat) regulates acts and are broadly divided into three categories, those are: first, hudud violation is a crime against Allah SWT and the punishment is clearly regulated in the Qur'an and Sunnah; secondly, Qishas are physical attacks and murders that are punished by retaliation. The victims or the heirs may decide to rule out the punishment, and demand compensation (diyat), the victim may also decide to pardon the offender; thirdly, Ta'zir is an unspecified punishment in the Qur'an or Sunnah, and exercised under the authority of the state through a judge. ${ }^{11}$

The settlement of the case through restorative justice in Islamic criminal law is based on the objective of Islamic law itself that is to realize the universal human benefit not only for the benefit of the individual. Nurcholish Madjid calls ishlah as a reformation. It is derived from the same words as "shalih" and "maslahah" (expediency). All refer to good meaning, kind-

Zvi D. Gabbay, “Justifying Restorative Justice: A Theoretical Justification for the Use of Restorative Justice Practices", Journal of Dispute Resolution, Vol. 2005, Issue 2, 2005, p. 9.

10 Septa Candra, "Restorative Justice: Suatu Tinjauan Terhadap Pembaharuan Hukum Pidana Di Indonesia", Jurnal RechtsVinding, Vol. 2 Issue. 2, August 2013, p. 264.

11 Etim E. Okon, "Hudud Punishments In Islamic Criminal Law" European Scientific Journal, Vol.10 No.14, May 2014, p. 228. ness, and improvement. ${ }^{12}$ Ishlah with a number of approaches are: reconciliation approach, forgiveness approach, apology approach, and deep regret approach.

The centrality of Islamic criminal law through restorative justice based on the principles and various sequences includes encouraging crime disregarding, forgiveness with suspended rights of God and human rights, interpersonal modification, arbitration, interference, compensation, repentance rules and indications of Islamic criminal policy abilities in the implementation of restorative justice completely. ${ }^{13}$

\section{Settlement of Jarimah Qishas through Restor- ative Justice}

Islamic criminal law embraced all alternative forms of punishment called as modern restorative justice. It has similar principle. Natangsa Surbakti explains that Islamic criminal law recognizes apology as important point in restorative justice, especially in Jarimah Qisas/diyat which is jarimah towards human being. ${ }^{14}$ Islamic criminal law considers human's soul not only has public dimension but also civil dimension.

The scholars know compensation practice (diya), conciliation (sulh), forgiveness (af'wu), apology, and public service, service on behalf of victim, warning, fine, probation sentence, and reintegration. They added unique mechanism which comes from broader principles of Islam; it can be understood as restorative means, such as repentance (taubah), take the benefit in doubt, secure privacy, syafaat, kafala, and kafarat. ${ }^{15}$

There are three principles suggested by the experts in doing restorative justice approach in Islamic criminal law such as: First, justice needs the healing for victim, offenders

12 Budi Munawar Rahman, 2012, Ensiklopedia Nurcholis Madjid, Jilid Dua, Jakarta: Yayasan Abad Demokrasi, p. 1121.

13 Mohammad Ali Heidari \& Masoma Porshabanan, "Study of Restorative Justice and Distributive Justice From the Perspective of Islamic Law and Jurisprudence", New York Science Journal, Vol. 8 No. 6, 2015, p. 80

14 Faizal Adi Surya, "Tinjaun Mediasi Penal dalam Perspektif Hukum Adat dan Hukum Islam” Jurisprudence, Vol. 5 Issue. 2, September 2015, p. 45.

15 Mutaz M. Qafisheh, "Restorative Justice in the Islamic Penal Law: A Contribution to the Global System", International Journal of Criminal Justice Sciences, Vol. 7 Issue 1, January-June 2012, p. 502. 
and communities who suffer from crime; secondly, victim, offenders and communities are allowed to actively involved in litigation on time and substance matter; third, the government role and responsibility must be reconsidered to promote justice. Government has the responsibility to keep the order and people are responsible to build peace. ${ }^{16}$

In accordance with the opinion above, according to Ramizah wan Muhammad, there are three major ideas from restorative justice. First, to fix. Crime causes loss and loss must be fixed. Qishas has caused loss for the victim, so the loss or the injury must be healed through Qishas and the offender must face punishment as retaliation and paying fine (diyat). Second, a meeting to solve a problem between the offender and the victim or family. Third, transformation elements have realized in law in purpose to change the offender. To restore justice, communities can minimize the crime as the important step. ${ }^{17}$

Hambali Yusuf and Saifullah Basri wrote that pattern of settlement model qishas-diyat can be traced by how to solve it using litigation and non-litigation. First, Model of litigation settlement applies qishas or a proper reprisal if the offender is not forgiven. Second, jarimah settlement is to apply it with non-litigation or reconciliation that the offender is forgiven by paying diyat or pay compensation. If it is agreed, diyat payment can free the offender from qishas. The third model is forgiving from victim or the family without paying back diyat or fine but judge can punish the offender with ta'zir. ${ }^{18}$

Criminal act which is done by restorative justice approach in Islam criminal law can be clustered into: property-related crime; crime against life or soul; crime against immorality; dignity-related crime; marriage administration provision-related crime; children's right-related crime.

16 Abdurrahman Raden Aji Haqqi, "Criminal Punishment And Pursuit Justice In Islamic Law", International Journal of Technical Research and Applications, Special Issue 15, January-February 2015, p. 1

17 Ramizah wan Muhammad, "Restorative Justice in Islamic Criminal Legal System", Journal of Islamic Law Review, Vol. 12 Issue. 2, December 2016, p. 207.

18 Hambali Yusuf and Saifullah Basri, Op.Cit., p. 80.
Crime related to property and immorality in Islam criminal law is included in jarimah hudud. Crime against life or soul physically in criminal law is regulated in jarimah qishas while crime related to dignity/pride, marriage administration provision and children's right is explained in ta'zir jarimah.

The principles of restorative justice in Islam can also be seen in punishment stipulation imposed for the murderer. Murder criminal act in Islamic law is imposed punishment in form of qishas (death sentence), diyat (fine), or forgiveness from victim's family. Those three punishments are alternative, not cumulative, meaning that if the first punishment has been determined, it cannot be added by the second punishment. The interesting thing is the option of the third punishment which is forgiveness from victim's family. Forgiveness becomes the reason of punishment annulment in Islamic law in which it is not found in criminal law in Indonesia. ${ }^{19}$

Allah SWT, in Qur'an Surah Al-Baqarah (2) Verse 178 , obliges qishas on murder case. However, in that verse, He gives the relief by opening the chance of forgiveness from victim's family to the murderer so the qishas is cancelled. In return, He relieves and gives His mercy to the people who have given the forgiveness and $\mathrm{He}$ will abort that qishas right.

Sayid Sabiq commented that the stipulation of Qur'an Surah Al-Baqarah (2): 178-178 related to qishas-diyat law contains several principles. First, Qishas is the correction form of jahiliyah law that is discriminative. Second, there are alternative laws namely qishas, diyat, or forgiveness. Third, there are relief and ease from Allah regarding the application of qishas law. Fourth, there is reconciliation system between the involved parties (victim or relative and offender). Fifth, in qishas, human live survival will be guaranteed safely. Qishas also becomes the deterrent to make people afraid of

\footnotetext{
1 Ali sodikin, "Restorative Justice dalam Tindak Pidana Pembunuhan: Perspektif Hukum Pidana Indonesia dan Hukum Pidana Islam", Asy-Syir'ah: Jurnal Ilmu Syari'ah dan Hukum, Vol. 49 Issue. 1, June 2015, p. 94.
} 
committing murder since the punishment is severe. ${ }^{20}$

The values of restorative justice in qishas law are manifested in the concepts human dignity, respect, community. Human dignity concept is clearly seen in qishas legal philosophy as stated in Qur'an Surah Al Baqarah verse 179, which is the protection of human life. ${ }^{21}$

Based on Islamic law, victim can return his or her rights through various ways. Victim or family insists on prosecuting the offender to impose retaliation or defend the original punishment. This is called as qishas or systematic retaliation. Furthermore, victim can offer three additional options: compensation, conciliation, or forgiveness. Compensation is placed upon temporary punishment meanwhile conciliation is placed upon compensation. ${ }^{22}$

Susan C. Hascall stated that restorative justice can be applied in qishas crime because victim or family has central role in doing prosecution and punishment toward the offender. The victim is given the options whether he or she wants to impose the punishment, forgive the offender, or command the offender to pay fine as compensation of the crime. Therefore, qishas law objectively supports restorative justice movement and it is very possible for victim or family to participate in giving forgiveness and reconciliation. ${ }^{23}$ The completion of case through ishlah way is truly recommended in Islam. It is regulated in Q.S. al-Hujurat (49) Verse 10 which emphasizes the importance of peace between two parties.

Furthermore, in Islam there is forgiveness institution in Islamic criminal law which supports each criminal case to be completed through restorative justice. This forgiveness concept in Islam is called as peace. It is as said by Allah SWT in Q.S. Asy-Syuura (42) Verse 40

20 Ifa Latifa Fitriani, Islam dan Keadilan Restroratif Pada Anak yang Berhadapan Dengan Hukum", In Right: Jurnal Agama dan Hak Azazi Manusia, Vol. 2 Issue.1, 2012, p. 222-223.

21 Ali sodikin, “Restorative Justice dalam...”, op.cit., p. 95.

22 Mutaz M. Qafisheh, Op.cit., p. 488.

23 Susan C. Hascall, "Restorative Justice in Islam: Should Qisas Be Considered a Form of Restorative Justice?" Berkeley Journal of Middle Eastern \& Islamic Law, Vol. 4, Article 2, 2012, p. 37-38. meaning that, "The recompense for an injury is an injury equal thereto (in degree): but if a person forgives and makes reconciliation, his reward is due from Allah. For (Allah) loveth not those who do wrong".

Referring to verses above, it points out: first, a person who commit crime will receive retaliation for his crime equally with what he did; second, the victim given an authority to do countermeasure; third, in countermeasure process, it is possible if there any reconciliation between offender, victim or his family; fourth, the victim or his family who forgive the offender and does not do any countermeasure shall surrender for their kindess in the hand of Allah swt. ${ }^{24}$

Reconciliation in Islamic criminal law requires three principles including disclosure of truth; there must be victim or family of victim and offender. Meanwhile neutral third parties help the conflicted parties to find resolution voluntarily without any forces in order to keep the balances of rights and obligations for each party. Moreover, reconciliation conceptually did not clean offender mistake, offender still uphold his/her commitment but he is given dispensation. ${ }^{25}$

Forgiveness or reconciliation in Islamic law view is punishment too, where the offender must apologize and regret for what he did to the victim. This gives a lesson that offender must admit his entire mistake first and admitting mistake is hard. Human always feels right for what they did even if law stated it as wrong action. ${ }^{26}$

Reconciliation implementation as applied in murder and torture has similarity with restorative justice application in modern criminal

24 Waluyadi, "Islam Menurut Hukum Islam Relevansinya dengan Hukum Pidana di Tingkat Penyidikan", Yustitia, Edisi 89, Mei-Agustus 2014, p. 36.

25 Aliflanya Arisandy Maghfirah et.al., "Sulh' In Islamic Criminal Law as The Form of Restorative Justice: A New Framework in Indonesian Criminal Law", Proceedings, Proceedings of Scientific Cooperations $2^{\text {nd }}$ International Conference on Social Sciences, Istambul Turkey, April $2^{\text {nd }}-3^{\text {rd }} 2016$, p. 225.

26 Rahmatiah HL, "Remisi Dalam Tindak Pidana Pembunuhan (Studi Perbandingan Hukum Pidana Islam dan Hukum Pidana Nasional) Jurnal Al-Qadāu, Vol. 1 No. 1, 2014, p. 12. 
law. Regardless from pro-contra of what kind of law that could be applied in restorative justice just like in Islamic or modern crimial law, it shoud be acknowledged that Islam had been practicing restorative justice before modern criminal law.

Restorative justice in Islamic criminal law is institutionalized in reconciliation (ishlah) and forgiveness (al-awfu). Ishlah is a process of settlement cases between parties that have been chosen by each party without forces or settled by third parties and ended with agreement to realize reconciliation in both of parties. Meanwhile, al'afwu is mediation of settlement qishah crime by dismissing qishas rights from victim to offender, which is still possible to do qishas. ${ }^{27}$ If there is an initiative to give compensation about qishas punishment coming from both parties, it is called ishlah (reconciliation). Meanwhile, if an initiative about the compensation just comes from one side (victim side), it categorizes as al'awfu (forgiveness). ${ }^{28}$

\section{Conclusion}

Restorative justice concept in Islamic criminal law is ishlah or reconciliation which begins with forgiveness. Restorative justice is an approach within criminal settlement. This approach emphasizes on direct participation from offender, victim, and community in settlement process. Restorative justice in Islamic criminal law is to create justice and balance for offender and victim.

Jarimah Qishas settlement is through restorative justice approach. The victim's family has the rights to determine punishment, whether it is qishas (killed), or diyat (compensation), or forgiveness. Those three alternative punishments and involvement of both parties show that Islamic criminal law applied restorative justice approach. Criminal settlement method which is called reconciliation (shulh), victim or his family are allowed to hold reconciliation by

\footnotetext{
27 Mahrus Ali and Syarif Nurhidayat, 2011, Penyelesaian Pelanggaran HAM Berat In Court System \& Out Court System, Jakarta: Gratama Publishing, p. 290.
}

28 Ibid., p. 292-293. replacing punishment with compensation that equal to diyat or more.

\section{References}

Ali, Mahrus dan Syarif Nurhidayat. 2011. Penyelesaian Pelanggaran HAM Berat In Court System and Out Court System. Jakarta: Gratama Publishing;

Candra, Septa. "Politik Hukum Pengadopsian Restorative Justice Dalam Pembaharuan Hukum Pidana". Fiat Justisia Jurnal IImu Hukum. Vol. 8 No. 2. April-June 2014. Pp. 255-277. DOI: 10.25041/fiatjustisia.v8no 2.301;

“Restorative Justice: Suatu Tinjauan Terhadap Pembaharuan Hukum Pidana Di Indonesia”. Jurnal RechtsVinding. Vol. 2 No. 2. August 2013. Pp. 263-277;

Fitriani, Ifa Latifa. "Islam dan Keadilan Restroratif Pada Anak yang Berhadapan Dengan Hukum". In Right: Jurnal Agama dan Hak Azazi Manusia. Vol. 2 No.1. 2012.Pp. 207238;

Gabbay, Zvi D. “Justifying Restorative Justice: A Theoretical Justification for the Use of Restorative Justice Practices". Journal of Dispute Resolution, Vol. 2005 Issue 2. 2005. Pp. 263-277;

Haqqi, Abdurrahman Raden Aji. "Criminal Punishment and Pursuit Justice In Islamic Law". International Journal of Technical Research and Applications. Special Issue 15. January-February 2015. Pp. 1-10;

Hascall, Susan C. "Restorative Justice in Islam: Should Qisas Be Considered a Form of Restorative Justice?". Berkeley Journal of Middle Eastern and Islamic Law, Vol. 4 Article 2. 2012. Pp. 35-78;

Heidari, Mohammad Ali and Masoma Porshabanan. "Study of Restorative Justice and Distributive Justice from the Perspective of Islamic Law and Jurisprudence". New York Science Journal. Vol. 8. No. 6. 2015. Pp. 80-85. DOI: $10.7537 /$ marsnys080615. 13 ;

Maghaireh, Alaeldin. "Shariah Law And CyberSectarian Conflict: How Can Islamic Criminal Law Respond To Cyber Crime?" International Journal of Cyber Criminology. Vol. 2 Issue 2. July-December 2008. Pp. 337-345.

Maghfirah, Aliflanya Arisandy. et.al. "Sulh' In Islamic Criminal Law as The Form of Res- 
torative Justice: A New Framework in Indonesian Criminal Law". Proceedings. Proceeding of Scientific Cooperations 2nd International Conference on Social Sciences of Istambul Turkey. April $2^{\text {nd }}-3^{\text {rd }}$ 2016;.

Muhammad, Ramizah wan. "Restorative Justice in Islamic Criminal Legal System". Journal of Islamic Law Review. Vol. 12 No. 2. December 2016. Page. 191-213;

Okon, Etim E. "Hudud Punishments In Islamic Criminal Law". European Scientific Journal. Vol. 10 No. 14. May 2014. Pp.227238;

Prayitno, Kuat Puji. "Restorative Justice untuk Peradilan di Indonesia (Perspektif Yuridis Filosofis dalam Penegakan Hukum In Concreto)". Jurnal Dinamika Hukum. Vol. 12 No. 3. September 2012. Pp. 407-420. DOI: 10.20884/1.jdh.2012.12.3.116;

Qafisheh, Mutaz M. "Restorative Justice in the Islamic Penal Law: A Contribution to the Global System". International Journal of Criminal Justice Sciences. Vol. 7 Issue 1. January-June 2012. Pp. 487-507;

Rahman, Budi Munawar. 2012. Ensiklopedia Nurcholis Madjid. Jilid Dua. Jakarta: Yayasan Abad Demokrasi;

Rahmatiah HL, "Remisi Dalam Tindak Pidana Pembunuhan (Studi Perbandingan Hukum Pidana Islam dan Hukum Pidana Nasional) Jurnal Al-Qadāu, Vol. 1 No. 1. 2014. Pp. 1-17;

Rajafi, Ahmad. "Qishash dan Maqashid Al-Syariah (Analisis Pemikiran asy-Syathibi dalam Kitab Al-Muwafaqat). Jurnal AlSyir'ah. Vol. 8 No. 2. December 2010. Page. 459-478;

Sodikin, Ali. "Restorative Justice dalam Tindak Pidana Pembunuhan: Perspektif Hukum Pidana Indonesia dan Hukum Pidana Islam". Asy-Syir'ah: Jurnal Ilmu Syari'ah dan Hukum, Vol. 49 No. 1. June 2015. Page. 63-100;

Surya, Faizal Adi. “Tinjaun Mediasi Penal Dalam perspektif Hukum Adat dan Hukum Islam" Jurisprudence, Vol. 5 No. 2. September 2015. Page. 118-126;

Waluyadi, "Islah Menurut Hukum Islam Relevansinya dengan Hukum Pidana di Tingkat Penyidikan", Yustitia, Edisi 89. Mei-Agustus 2014. Pp. 29-42. DOI: $10.20961 /$ yustisia. v3i2.11090;
Yusuf, Hambali and Saifullah Basri, "Model Penyelesaian Alternatif Perkara Pidana Pembunuhan Biasa menurut Hukum Islam dan Relevansinya dengan Pembaharuan Hukum Pidana Indonesia", Jurnal Hukum IUS QUIA IUSTUM, No. 1 Vol. 24. Januari 2017. Pp. 73-93. DOI: 10.20885/iustum. vol24.iss1.art4;

Zainuddin. 2013. Hukum Zakat: Perspektif Normatif, Kesejahteraan dan Keradilan Sosial. Makassar: Alauddin University Press;

Zulfa, Eva Achjani. "Restorative Justice in Indonesia: Traditional Value". Indonesia Law Review. Vol. 2 No. 1. May-August 2011. Pp. 33-43. DOI: 10.15742/ilrev.v1 $\mathrm{n} 2.81$. 